\title{
Phytomass production and nutrient accumulation by green manure species ${ }^{1}$
}

\author{
José Carlos Soares Mangaravite, Renato Ribeiro Passos ${ }^{3}$, Felipe Vaz Andrade, \\ Diego Lang Burak, Eduardo de Sá Mendonça ${ }^{6}$ \\ http://dx.doi.org/10.1590/0034-737X201461050017
}

\begin{abstract}
Green manuring is recognized as a viable alternative to improve nutrient cycling in soils. The aim of this study was to evaluate the phytomass production and nutrient accumulation in shoots of the summer green manures jack bean [Canavalia ensiformis (L.) DC.], dwarf pigeon pea (Cajanus cajanvar var. Flavus DC.), dwarf mucuna [Mucuna deeringiana (Bort) Merr] and sunn hemp (Crotalaria juncea L.), under nitrogen fertilization and/or inoculation with $\mathrm{N}$-fixing bacteria. A split plot design was arranged with the four Fabaceae species as main plots and nitrogen fertilization (with and without) and inoculation with diazotrophic bacteria (with and without) as the subplots, in a $2^{2}$ factorial. The experiment was arranged as a randomized complete block design with four replications. In the conditions of this trial, the sunn hemp had the highest production of shoot phytomass $\left(12.4 \mathrm{Mg} \mathrm{ha}^{-1}\right)$ and nutrient accumulation, while the dwarf mucuna had the lowest production of shoot phytomass $\left(3.9 \mathrm{Mg} \mathrm{ha}^{-1}\right)$ and nutrient accumulation. The results showed no effect of nitrogen fertilization or inoculation with $\mathrm{N}$-fixing bacteria on the production of shoot phytomass and nutrient accumulation, except for inoculation without nitrogen fertilization, resulting in greater $\mathrm{P}$ accumulation ( $\mathrm{p}<0.05)$ in the sunn hemp and greater $\mathrm{Zn}$ and $\mathrm{Mn}$ accumulation in the dwarf mucuna. These findings indicate that $\mathrm{N}$ fertilization or inoculation with $\mathrm{N} 2$-fixing bacteria for Fabaceae are low efficiency practices in the edaphoclimatic conditions of this study.
\end{abstract}

Key words: biological nitrogen fixation, green manure, Fabaceae, legumes, nutrient accumulation.

\section{RESUMO}

\section{Produção de fitomassa e acúmulo de nutrientes por espécies utilizadas na adubação verde}

A adubação verde é reconhecida como alternativa viável para melhorar a ciclagem de nutrientes em solos agrícolas. O objetivo deste trabalho foi avaliar a produção de fitomassa e o acúmulo de nutrientes na parte aérea de adubos verdes de verão: feijão-de-porco [Canavalia ensiformis (L.) DC.], guandu-anão (Cajanus cajanvar var. Flavus DC.), mucuna-anã [Mucuna deeringiana (Bort) Merr] e crotalária (Crotalaria juncea L.), sob efeito da adubação nitrogenada e, ou, da inoculação com bactérias fixadoras de N. Utilizou-se o arranjo de parcelas subdivididas, sendo as parcelas constituídas pelas quatro fabáceas e, as subparcelas, por um fatorial $2^{2,}$ cujos fatores e níveis foram:

\footnotetext{
Received: 15/04/2013 Approved: 09/09/2013.

'Part of the first author Master's Dissertation submitted to the Graduate Program in Plant Production Center of Agricultural Science of the Federal University of Espírito Santo. ${ }^{2}$ Agronomist, Master of Science. Escritório Local de Desenvolvimento Rural, Instituto Capixaba de Assistência Técnica e Extensão Rural, Rua Carlos Gomes Lucas, 13, Bela Vista, 29290000, Rio Novo do Sul, Espírito Santo, Brasil, mangaravite3@ hotmail.com

${ }^{3}$ Agronomist, Doctor of Science. Departamento de Produção Vegetal, Centro de Ciências Agrárias da Universidade Federal do Espírito Santo, Alto Universitário, s/n, Caixa Postal 16, Guararema, 29500000, Alegre, Espírito Santo, Brasil. renatoribeiropassos@ hotmail.com (corresponding author)

${ }^{4}$ Agronomist, Doctor of Science. Departamento de Produção Vegetal, Centro de Ciências Agrárias da Universidade Federal do Espírito Santo, Alto Universitário, sem número, Caixa Postal 16, Guararema, 29500000, Alegre Espírito Santo, Brasil. felipevazandrade @ gmail.com

${ }^{5}$ Agronomist, Doctor of Science. Departamento de Produção Vegetal, Centro de Ciências Agrárias da Universidade Federal do Espírito Santo, Alto Universitário, s/n , Caixa Postal 16, Guararema, 29500-000, Alegre, Espírito Santo, Brasil. dlburak@hotmail.com

${ }^{6}$ Agronomist, Doctor of Science. Departamento de Produção Vegetal, Centro de Ciências Agrárias da Universidade Federal do Espírito Santo, Alto Universitário, s/n, Guararema, 29500-000, Caixa Postal 16, Alegre, Espírito Santo, Brasil. eduardo.mendonca@ufes.br
} 
adubação nitrogenada (com e sem) e inoculação com bactérias diazotróficas (com e sem). O delineamento experimental adotado foi o de blocos casualizados, com quatro repetições. Nas condições edafoclimáticas deste ensaio, a crotalária é o adubo verde que apresenta os maiores valores de produção de fitomassa aérea $\left(12,4 \mathrm{Mg} \mathrm{ha}^{-1}\right) \mathrm{e}$ acumulação de nutrientes, enquanto a mucuna-anã é a menos eficiente na produção de fitomassa aérea $\left(3,9 \mathrm{Mg} \mathrm{ha}^{-1}\right)$ e acúmulo de nutrientes. Os resultados mostram que não há efeito de adubação nitrogenada, ou de inoculação com bactérias fixadoras de $\mathrm{N}$, na produção de fitomassa aérea ou acúmulo de nutrientes, com exceção da inoculação na ausência de adubação nitrogenada, que resultou $(\mathrm{p}<0,05)$ em maior acumulação de $\mathrm{P}$, na crotalária, e maior acumulação de Zn e Mn, na mucuna-anã. Conclui-se que a adubação nitrogenada ou a inoculação com bactérias fixadoras de $\mathrm{N}_{2}$, para o cultivo das fabáceas, são práticas de baixa eficiência nas condições edafoclimáticas estudadas.

Palavras-chave: fixação biológica de nitrogênio, adubação verde, fabáceas, leguminosas, acumulação de nutrientes.

\section{INTRODUCTION}

Green manuring is a practice that allows the input of large amounts of biomass, increasing, over the years, nutrient content and organic matter in the soil for subsequent crops through nutrient cycling. However, according to Cherr et al. (2006), although this practice is economically feasible and reduces the environmental impacts of agriculture, its use is limited by the lack of information on its complexity and the interaction between green manures, management and soils for different edaphoclimatic conditions.

Within the steps of nutrient cycling, shoot biomass and nutrient content are the main components of the nutrient balance in the soil-plant system. Subsequent steps, which are important for green manuring success, will depend on the quality of residues produced, amount of nutrients released during decomposition and temporal synchronization between nutrients released by residue decomposition and crop requirement (Matos et al., 2008).

Therefore, the Fabaceae to be used as green manure is selected preferably among species that produce greater volume of dry matter, are less susceptible to pests, diseases and water and nutritional stresses and have relatively uniform seeds that are suitable for seeders (Miyasaka, 1984). Among the species with these characteristics, sunn hemp (Crotalaria juncea L.), dwarf pigeon pea (Cajanus cajanvar var. Flavus DC), jack bean [Canavalia ensiformis (L.) DC] and dwarf mucuna [Mucuna deeringiana (Bort) Merr.] are annual plants that can achieve on average dry matter yields of 19.3, 7.0, 6.6, and 3.3 $\mathrm{Mgha}^{-1}$, respectively (Calegari et al., 1993).

Plant species other than Fabaceae (also called legumes) can be used for green manure, but they have been preferred especially because of their symbiotic association with diazotrophs, increasing atmospheric $\mathrm{N}_{2}$ fixation through root nodule formation (Miyasaka, 1984).
Thus, there is a reduction in the demand for nitrogen fertilizers, in addition to other nutrients cycled by these plants. Among the bacteria associated with plants of the Fabaceae family, the genera Rhizobium, Bradyrhizobium, Sinorhizobium, Mesorhizobium and Azorhizobium, which are collectively identified as rhizobia (Vieira, 2007), stand out for being able to convert atmospheric $\mathrm{N}_{2}$ into ammonia, which is incorporated in different forms of organic $\mathrm{N}$ for use by the host plants (Epstein \& Bloom, 2006).

The occurrence of active nodules depends, besides the optimization of nutritional and climatic factors, on the presence of effective rhizobia in the Fabaceae rhizosphere for an optimal interaction between the plant and the bacteria (Long, 2001; Epstein \& Bloom, 2006; Taiz \& Zeiger, 2009). The presence of ineffective rhizobial strains can compromise the soil symbiotic $\mathrm{N}_{2}$ fixation (Calegari et al. 1993). Accordingly, native rhizobial strains have been promising, with greater efficiency of inoculation and nitrogen fixation (Lima $e t$ al., 2012).

The objective of this study was to evaluate the phytomass production and nutrient accumulation in shoots of four Fabaceae species inoculated and noninoculated with $\mathrm{N}$-fixing bacteria in the presence and absence of nitrogen fertilization.

\section{MATERIALS AND METHODS}

The experiment was conducted at the Fazenda Experimental de Bananal do Norte, Pacotuba district, in Cachoeiro de Itapemirim, Southern Espírito Santo State, belonging to the Instituto Capixaba de Pesquisa, Assistência Técnica e Extensão Rural (Incaper), located at $20^{\circ}$ $45^{\prime} 11^{\prime \prime} \mathrm{S}$ and $41^{\circ} 17^{\prime} 39^{\prime \prime} \mathrm{O}$ and $102 \mathrm{~m}$ of altitude. The climate is Cwa type, with rainy summers and dry winter, according to the classification of Köeppen. The average annual rainfall (1982 - 2007) is $1,209 \mathrm{~mm}$, with an 
average of 110 days of rain per year. The region has high climate seasonality, with well-defined low and high rainfall seasons. The soil is a clay Red-Yellow Latosol, wavy relief (20\% slope), with the following chemical characteristics $(0-20 \mathrm{~cm})$ : $\mathrm{pH}$ in $\mathrm{H}_{2} \mathrm{O}(1: 2.5), 5.9$; $\mathrm{Al}^{+3}$, $0.0 \mathrm{cmol}_{\mathrm{c}} \mathrm{dm}^{-3} ; \mathrm{Ca}^{+2}, 2.8 \mathrm{cmol}_{\mathrm{c}} \mathrm{dm}^{-3} ; \mathrm{Mg}^{+2}, 0.8 \mathrm{cmol}_{\mathrm{c}} \mathrm{dm}^{-}$ ${ }^{3} ; \mathrm{K}^{+}, 129 \mathrm{mg} \mathrm{dm}^{-3}$; available P, $29.0 \mathrm{mg} \mathrm{dm}^{-3} ; \mathrm{Fe}, 134 \mathrm{mg}$ $\mathrm{dm}^{-3} ; \mathrm{Mn}, 53 \mathrm{mg} \mathrm{dm}^{-3} ; \mathrm{Zn}, 7.2 \mathrm{mg} \mathrm{dm}^{-3} ; \mathrm{Cu}, 1.2 \mathrm{mg} \mathrm{dm}^{-3}$; B, $0.03 \mathrm{mg} \mathrm{dm}^{-3}, \mathrm{Mo},<0.1 \mathrm{mg} \mathrm{dm}^{-3}$ and Co, $0.25 \mathrm{mg} \mathrm{dm}^{-}$ ${ }^{3}$ of soil. Regarding the particle size analysis, the results were: coarse sand, $424 \mathrm{~g} \mathrm{~kg}^{-1}$; fine sand, $176 \mathrm{~g} \mathrm{~kg}^{-1}$; silt, $49 \mathrm{~g} \mathrm{~kg}^{-1}$; Clay $349 \mathrm{~g} \mathrm{~kg}^{-1}$.

A split plot design was arranged with the Fabaceae species jack bean [Canavalia ensiformis (L.) DC.], dwarf pigeon pea (Cajanus cajanvar var. Flavus DC.), dwarf mucuna [Mucuna deeringiana (Bort) Merr] and sunn hemp (Crotalaria juncea L.) as main plots and nitrogen fertilization (with and without) and inoculation with diazotrophic bacteria (with and without) as the subplots, in a $2^{2}$ factorial. The experiment was arranged as a randomized complete block design with four replications.

Each experimental unit was $16 \mathrm{~m}^{2}(4 \mathrm{~m} \mathrm{x} 4 \mathrm{~m})$, with $4 \mathrm{~m}^{2}(2 \mathrm{~m} \times 2 \mathrm{~m})$ of harvest area and $1 \mathrm{~m}$ border on each end of the harvest area. The experimental area of this work was previously occupied with pasture, corn cultivation and Mombaça grass (Panicum maximum cv. Mombaça) experiment, without any of the Fabaceae species cultivated in this experiment.

A total of $900 \mathrm{~kg} \mathrm{ha}^{-1}$ dolomitic limestone $(100 \%$ CCE) was incorporated into the soil by disking. Fertilization followed the same recommendation for common-bean, without irrigation, according to Prezotti et al. (2007). $\mathrm{P}$ and $\mathrm{K}$ were broadcast over the entire area, immediately before planting and incorporated by disking. The rates $450 \mathrm{~kg} \mathrm{ha}^{-1}$ of $\mathrm{P}_{2} \mathrm{O}_{5}$ and $20 \mathrm{~kg} \mathrm{ha}^{-1} \mathrm{~K}_{2} \mathrm{O}$ were applied, respectively, in the form of single superphosphate $\left(18 \% \mathrm{P}_{2} \mathrm{O}_{5}\right)$ and potassium chloride $\left(60 \% \mathrm{~K}_{2} \mathrm{O}\right)$.

Mo and Co was applied to seeds and carried out prior to the sowing day and immediately before the inoculation of seeds with Rhizobia, using a commercial product for soybean, containing $1 \%$ Co and $10 \%$ Mo. A rate of 200 $\mathrm{ml}$ was mixed with a sufficient amount of seeds for sowing 1.0 ha. Half of the planted seeds of each species were inoculated with bacteria of the genus Bradyrhizobium, from the Diazotrophic Culture Collection of Embrapa Agrobiology, which are commercially recommended according to the method proposed by Embrapa Agrobiology (2009). The following strains were used: BR 2003 (=SEMIA 6156) with BR 2811 (=SEMIA 6158) in the mixture for jack bean; BR 2003 (=SEMIA 6156) and BR 2801 (=SEMIA 6157) in the mixture for dwarf pigeon pea; BR 2811 (=SEMIA 6158) for dwarf mucuna; and BR 2001 (=SEMIA 4145) with BR 2003 (=SEMIA 6156) for sunn hemp.

Sowing was carried out on November 13, 2009, in furrows with the spacing of $0.25 \mathrm{~m}$ between lines for sunn hemp and $0.50 \mathrm{~m}$ for the other Fabaceae. The seed density was according to the recommendation of Embrapa Agrobiologia (2009), with final plant stands for jack bean, sunn hemp, dwarf mucuna and dwarf pigeon pea of $8,11,12$ and 18 plants per meter, respectively, after thinning performed 16 days after sowing (DAS). Weeding was undertaken at 20 DAS and nitrogen fertilization at $31 \mathrm{DAS}$, applying $40 \mathrm{~kg} \mathrm{ha}^{-1}$ of $\mathrm{N}$ as urea $(45 \% \mathrm{~N})$ only to the rows of the subplots planned to receive $\mathrm{N}$. The legumes were cut when showing more than $70 \%$ flowering, which were 74 DAS for jack bean, 88 DAS for dwarf pigeon pea, 104 DAS for dwarf mucuna and 132 DAS for sunn hemp.

Immediately after the cutting of legumes, the total green matter was weighed, as well as samples from aerial parts of three plants from each subplot, to be used as a reference in determining the total phytomass, from the weight of before and after drying in a forced circulation oven at $65{ }^{\circ} \mathrm{C}$ to constant weight.

Chemical analyses were carried out with samples of about $500 \mathrm{~g}$ of the aerial part of each plant that were crushed and mixed in the pulper/chipping hammer mill, dried in a forced circulation oven at $65{ }^{\circ} \mathrm{C}$ to constant weight and ground in Willey mill.

Samples of each treatment were subjected to nitroperchloric digestion (ratio 4:1), according to EMBRAPA (2009), for determining contents of K (flame photometry), $\mathrm{P}$ (spectrophotometry with bluemolybdenum) and $\mathrm{Ca}, \mathrm{Mg}, \mathrm{Fe}, \mathrm{Zn}, \mathrm{Mn}$ and $\mathrm{Cu}$ (atomic absorption spectrophotometry). The contents of $\mathrm{C}$ and $\mathrm{N}$ were determined in an elemental analyzer CHNS / O Perkin Elmer 2400 Series II.

To compare the phytomass production and nutrient accumulation of the four species (plots), as well as between the treatments (subplots) with and without inoculation and/or with and without nitrogen fertilization (NI) within each species, contrasts originated from the unfolding of the three degrees of freedom for the species and the treatments were established as proposed by Alvarez V. \& Alvarez (2006). The contrasts between the species were established as shown in Table 1. The contrast 1 (C1) compared the sunn hemp, which is widely used as green manure and reported as the Fabaceae of greatest phytomass input (Amabile et al., 2000; Teodoro et al., 2011; Monquero et al., 2013). The contrast 2 (C2) compared the dwarf mucuna, which is considered as more rustic, more resistant to water deficit, with lower fertility requirement and lower sensitivity to acidity compared to 
other Fabaceae (Embrapa Agrobiologia, 2009). The contrast 3 (C3) compared the Fabaceae with a more herbaceous aspect (jack bean and dwarf mucuna), with more fibrous characteristics (sunn hemp and dwarf pigeon pea).

Among the treatments with and without inoculation and/or with and without nitrogen fertilization (NI), three different comparisons were established as contrasts to study the effects of the subplots for each Fabaceae (Table 2). The significance of the contrasts was determined by the $F$ test $(p \leq 0.01,0.05$ and 0.10$)$ using the GENES software (Cruz, 2006) to determine the mean squared residues, and the SAEG 9.0 software (SAEG, 2005) to calculate the mean squares for each contrast.

\section{RESULTS AND DISCUSSION}

\section{Phytomass production and nutrient accumulation}

The sunn hemp had significantly more phytomass and accumulation of most nutrients than the other three Fabaceae species as shown by contrast 1 (Tables 3 and 4). In general, the lowest values of phytomass and nutrient accumulation were found for dwarf mucuna, in the edaphoclimatic conditions of this study (Tables 3 and 4).

Higher phytomass production of sunn hemp, in comparison to other Fabaceae, has been reported in the literature (Amabile et al., 2000; Teodoro et al., 2011; Monquero et al., 2013). Pereira et al. (2012) obtained higher phytomass accumulation for sunn hemp $(C$.

Table 1. Contrasts created to compare means of phytomass production, accumulations of macro and micronutrients and $\mathrm{C} / \mathrm{N}$ and $\mathrm{C} / \mathrm{P}$ ratios of four Fabaceae species

\begin{tabular}{lccc}
\hline \multirow{2}{*}{ Species } & C1 & C2 & C3 \\
\cline { 2 - 4 } Jack bean & \multicolumn{3}{c}{ Contrast coefficients } \\
\cline { 2 - 4 } Dwarf pigeon pea & $+1 / 3$ & $-1 / 3$ & $+1 / 2$ \\
Dwarf mucuna & $+1 / 3$ & $-1 / 3$ & $-1 / 2$ \\
Sunn hemp & $+1 / 3$ & +1 & $+1 / 2$ \\
\hline
\end{tabular}

Table 2. Contrasts created to compare the treatments with and without $\mathrm{N}$ and/or with and without inoculant, for each of the four Fabaceae studied

\begin{tabular}{lccc}
\hline & \multicolumn{3}{c}{ Contrasts } \\
\cline { 2 - 4 } Treatments $^{(1)}$ & $\mathbf{4}$ Contrast coefficients \\
\cline { 2 - 4 } & $+1 / 2$ & +1 & 0 \\
\hline CNCI $^{1}$ & $+1 / 2$ & -1 & 0 \\
$\mathrm{CNSI}^{2}$ & $-1 / 2$ & 0 & +1 \\
$\mathrm{SNCI}^{3}$ & $-1 / 2$ & 0 & -1 \\
SNSI $^{4}$ & $\mathbf{5 / 8 / 1 1 / 1 3 ^ { ( 2 ) }}$ &
\end{tabular}

${ }^{(1)}$ CNSI: With nitrogen and without inoculant; CNCI: With nitrogen and with inoculant; SNCI: Without nitrogen and with inoculant, and SNSI: Without nitrogen and without inoculation.

(2)Jack bean: C4, C5, C6; Dwarf pigeon pea: C7, C8, C9; Dwarf mucuna: C10, C11, C12; and Sunn hemp: C13, C14, C15 juncea) than jack bean, dwarf pigeon pea and dwarf mucuna among other green manures, corroborating the results of Table 3. On the other hand, Cavalcante et al. (2012) found no differences among the phytomass productions of sunn hemp, dwarf pigeon pea and jack bean. Leal et al. (2012), in the State of Rio de Janeiro, worked with sunn hemp planted in mid-spring, cutting at four months of age and average annual rainfall of 1200 $\mathrm{mm}$, in similar conditions of this study, and found 213.5 $\mathrm{kg} \mathrm{ha}^{-1}$ of $\mathrm{N}$ and $12,362 \mathrm{~kg} \mathrm{ha}^{-1}$ of phytomass (dry matter) accumulated in the aerial part.

It is worth noting that the difference in the sowing time, which influences the photoperiod, can reduce, in some situations, the phytomass production of sunn hemp in relation to mucuna, which stands out under greater water stress conditions (Santos \& Campello Junior, 2003). The differences in phytomass production found with the same green manure can be attributed to soil type, environmental conditions (temperature, humidity, light), crop management (plant density, single/mixed intercropping systems), water and nutrient availability, harvest date and other factors affecting the yield and nutrient uptake of green manures (Cherr et al., 2006). Teodoro et al. (2011) recommended the cutting and the incorporation of Fabaceae in the flowering period, for the highest input of $\mathrm{N}, \mathrm{P}$ and $\mathrm{K}$ into agroecosystems.

The amount of $\mathrm{C}, \mathrm{N}, \mathrm{P}, \mathrm{K}, \mathrm{Ca}$ and $\mathrm{Mg}$ accumulated in shoots of the herbaceous Fabaceae obtained in this study were higher than those reported by Matos et al. (2011) for black mucuna, peanut and calopo, also herbaceous Fabaceae, in coffee plantations under agroforestry systems. These results can be explained by the milder climate.

The sunn hemp stood out for having the highest accumulation of $\mathrm{P}$ and $\mathrm{Mg}$. The dwarf mucuna had the lowest phytomass production and, consequently, less accumulation of $\mathrm{N}, \mathrm{P}, \mathrm{K}, \mathrm{C}, \mathrm{Ca}, \mathrm{Mg}$ and $\mathrm{Zn}$, which was demonstrated by the significant negative values in $\mathrm{C} 2$ (Table 4). This Fabaceae was superior to the other three species only for $\mathrm{Cu}$ accumulation $(\mathrm{p} \leq 0.01)$, which is associated with the higher content of this micronutrient (9.14 $\left.\mathrm{mg} \mathrm{kg}^{-1}\right)$ in the aerial part of the plants compared to jack bean (4.36 $\left.\mathrm{mg} \mathrm{kg}^{-1}\right)$, dwarf pigeon pea (4.52 mg $\left.\mathrm{kg}^{-1}\right)$ and sunn hemp $\left(2.38 \mathrm{mg} \mathrm{kg}^{-1}\right)$. This result may be related to the concentration effect for $\mathrm{Cu}$ in the dwarf mucuna, which showed lower phytomass production, and to the dilution effect in the sunn hemp, which was better in terms of phytomass production (Table 3) (Jarrell \& Beverly, 1981). Also, some Mucuna genera have been recognized in the literature as $\mathrm{Cu}$ phyto-extractors (Nwaichi et al., 2009; Omosun et al., 2010; Vendruscolo, 2013), suggesting a similar behavior for Mucuna deeringiana (Bort) Merr in this study. 
Bueno et al. (2007), studying four species of mucuna in Piracicaba - SP, obtained $8.4 \mathrm{Mg} \mathrm{ha}^{-1}$ of dry phytomass for dwarf mucuna (average of two years of production) and accumulations, in $\mathrm{kg} \mathrm{ha}^{-1}$, of 218.48, 14.86, 138.72, 45.14 and 14.79, respectively, for $\mathrm{N}, \mathrm{P}, \mathrm{K}, \mathrm{Ca}$ and $\mathrm{Mg}$. However, Silva (2006) obtained 1.7 $\mathrm{Mg} \mathrm{ha}^{-1}$ and $1.46 \mathrm{Mg}$ ha $^{-1}$ of dry phytomass of dwarf mucuna intercropped with cabbage and corn, respectively, and average accumulation of $66.3 \mathrm{~kg} \mathrm{ha}^{-1} \mathrm{~N}$ of phytomass, showing variation in yield as a function of different edaphoclimatic factors and management.

Besides the role in accumulation, it is important to study the rate of nutrient release in nutrient cycling by green manures. The sunn hemp showed the highest $\mathrm{C} / \mathrm{N}$ ratio (31.70), suggesting a lower phytomass decomposition rate and a slower nutrient release than the other Fabaceae (Tables 3 and 4). For N, P, Ca, Cu and $\mathrm{C} / \mathrm{P}$ ratio, the sunn hemp was not significantly different from the mean among jack bean, dwarf pigeon pea and dwarf mucuna as shown by the contrast 1 (Table 4). In this context, there is a greater potential for nutrient release with lower values for $\mathrm{C} / \mathrm{N}$ and $\mathrm{C} / \mathrm{P}$ ratios of dwarf mucuna compared with the other three Fabaceae.

The comparison of the four Fabaceae species (jack bean, dwarf pigeon pea, dwarf mucuna and sunn hemp) regarding phytomass production and nutrient accumulation by the contrasts $\mathrm{C} 1, \mathrm{C} 2$ and C3 (Table 4) showed that the sunn hemp has the greatest potential for use as green manure in relation to the other three Fabaceae, considering the higher phytomass production and higher accumulation of $\mathrm{K}, \mathrm{Mg}, \mathrm{Fe}, \mathrm{Zn}$ and $\mathrm{Mn}$ (C1 - Table 4).

Comparing the two more herbaceous Fabaceae (jack bean and dwarf mucuna) with the more fibrous ones (sunn hemp and dwarf pigeon pea) by contrast 3 (Table 4), it was found that the more fibrous ones had higher phytomass yields and higher accumulations of $\mathrm{C}, \mathrm{Mn}(\mathrm{p} \leq 0.01)$ and
Fe $(\mathrm{p} \leq 0.10)$, whereas the most herbaceous Fabaceae had higher accumulation of $\mathrm{Ca}(\mathrm{p} \leq 0.01)$ (Table 4$)$. It is interesting that despite the significance of the contrast 3 for $\mathrm{Ca}$ accumulation, the Fabaceae sunn hemp (more fibrous) and dwarf mucuna (more herbaceous) had close means, while dwarf pigeon pea (more fibrous) had the lowest mean $\left(32.3 \mathrm{~kg} \mathrm{ha}^{-1}\right)$ and jack bean had the highest mean $\left(124.8 \mathrm{~kg} \mathrm{ha}^{-1}\right)$. The accumulations of $\mathrm{N}, \mathrm{K}, \mathrm{Zn}$ and $\mathrm{Cu}$ (C3 - Table 4) showed no significant differences up to $10 \%$ probability by the $\mathrm{F}$ test. The herbaceous Fabaceae (jack bean and dwarf mucuna) showed a greater potential for decomposition and nutrient release, with the lowest $\mathrm{C} / \mathrm{N}$ and $\mathrm{C} / \mathrm{P}$ ratios (C3 - Table 4).

\section{Effect of nitrogen fertilization and inoculation}

There was no significant difference between the treatments with and without mineral nitrogen and/or with and without inoculation with diazotrophic bacteria for jack bean and dwarf pigeon pea in phytomass production and accumulation of macro and micronutrients ( $\mathrm{C} 4$ to C9 - Table 5). Except for the dwarf pigeon pea, the treatments with nitrogen fertilizer were less efficient for $\mathrm{Cu}$ accumulation than those without mineral $\mathrm{N}$ (C7 Table 5). This result indicates the occurrence of antagonistic effect between $\mathrm{N}$ and $\mathrm{Cu}$ similar to that proposed by Marschner (1997), considering that the lowest $\mathrm{Cu}$ content is associated with the application of mineral N. The increased availability of $\mathrm{N}$ influences the $\mathrm{Cu}$ availability and reduces the retranslocation rate of this micronutrient from the oldest leaves to the growing tissues (Marschner, 1997).

For the dwarf mucuna, the treatments with $\mathrm{N}$ fertilization (with and without inoculation) were more efficient in the accumulation of $\mathrm{N}, \mathrm{K}(\mathrm{p} \leq 0.10)$ and $\mathrm{Fe}(\mathrm{p}$ $\leq 0.01)$ than those without the mineral fertilizer $(\mathrm{C} 10$ Table 5).

Table 3. Phytomass production (DM), nutrient accumulation and $\mathrm{C} / \mathrm{N}$ and $\mathrm{C} / \mathrm{P}$ ratios in shoots of four green manure Fabaceae

\begin{tabular}{lrrrr}
\hline Variable & Jack bean $^{(\mathbf{1})}$ & Dwarf pigeon pea $^{(\mathbf{1})}$ & Dwarf mucuna $^{(\mathbf{1})}$ & Sunn hemp $^{(\mathbf{1})}$ \\
\hline $\mathrm{MS}\left(\mathrm{kg} \mathrm{ha}^{-1}\right)$ & $6,194.73$ & $6,927.82$ & $3,905.59$ & $12,487.95$ \\
$\mathrm{~N}\left(\mathrm{~kg} \mathrm{ha}^{-1}\right)$ & 213.07 & 188.40 & 163.10 & 201.65 \\
$\mathrm{P}\left(\mathrm{kg} \mathrm{ha}^{-1}\right)$ & 16.74 & 14.95 & 11.49 & 26.27 \\
$\mathrm{~K}\left(\mathrm{~kg} \mathrm{ha}^{-1}\right)$ & 192.21 & 94.85 & 86.43 & 167.32 \\
$\mathrm{C}\left(\mathrm{kg} \mathrm{ha}^{-1}\right)$ & 2612.35 & 3177.05 & 1675.88 & 5425.76 \\
$\mathrm{Ca}\left(\mathrm{kg} \mathrm{ha}^{-1}\right)$ & 124.84 & 32.33 & 61.25 & 69.32 \\
$\mathrm{Mg}\left(\mathrm{kg} \mathrm{ha}^{-1}\right)$ & 14.33 & 8.62 & 19.66 & 55.12 \\
$\mathrm{Fe}\left(\mathrm{g} \mathrm{ha}^{-1}\right)$ & 1,880 & 2,040 & 1,950 & 2,830 \\
$\mathrm{Mn}\left(\mathrm{g} \mathrm{ha}^{-1}\right)$ & 230 & 230 & 180 & 310 \\
$\mathrm{Zn}\left(\mathrm{g} \mathrm{ha}^{-1}\right)$ & 240 & 120 & 320 & 380 \\
$\mathrm{Cu}\left(\mathrm{g} \mathrm{ha}^{-1}\right)$ & 30 & 30 & 40 & 30 \\
Relação C/N & 14.42 & 19.93 & 12 & 31.70 \\
Relação C/P & 405.28 & 557.76 & 380.62 & 539.24 \\
\hline
\end{tabular}

${ }^{(1)}$ Mean of four treatments with and without nitrogen and/or inoculant. 
The tendency of greater $\mathrm{N}$ accumulation by the dwarf mucuna is associated with the $\mathrm{N}$ input through mineral fertilization and the higher $\mathrm{K}$ accumulation is associated with the application of mineral $\mathrm{N}$, demonstrating the synergistic effect between the two macronutrients, that is, the absorption of an element increases the demand for the other (Cantarella, 2007). The supply of $\mathrm{N}$ and K often increases the response to the two elements, both in production and in nutrient accumulation (Cantarella, 2007). In this study, the $\mathrm{K}$ fertilization was performed according to the soil analysis and uniformly distributed throughout the experimental area. Worth of noting is the negative contrast in relation to sunn hemp DM, indicating a great potential for $\mathrm{N}$ accumulation in unfertilized conditions, which makes the species interesting for the sustainability of nutrient cycling in less fertile environments.

The dwarf Mucuna treatments with mineral N (C11 Table 5), but without inoculation with diazotrophs, were more efficient in the accumulation of $\mathrm{Fe}(\mathrm{p} \leq 0.01), \mathrm{P}$ and $\mathrm{Mn}(\mathrm{p} \leq 0.10)$ than those inoculated. Among the treatments without $\mathrm{N}$ fertilization $(\mathrm{C} 12$ - Table 5), the highest accumulations of $\mathrm{Zn}, \mathrm{Mn}(\mathrm{p} \leq 0.05)$ and $\mathrm{Cu}$ $(p \leq 0.10)$ were observed in shoots of plants derived from non-inoculated seeds. According to Moreira \& Siqueira (2006), the availability of mineral $\mathrm{N}$ drastically reduces nodulation in Fabaceae, as it occurs in response to plant nutritional demand for N. Taiz \& Zeiger (2009) stated that the presence of mineral $\mathrm{N}$ inhibits the stimulus to nodulation. Thus, the non-significant difference of the accumulated $\mathrm{N}$ identified by $\mathrm{C} 14$ is due to the low nodulation rate under nitrogen fertilization. However, it does not explain the lower accumulation of dry matter (DM), C, P, K and Zn.

The contrast between the treatments with and without inoculants for sunn hemp plants that did not receive mineral $\mathrm{N}$ fertilizer $(\mathrm{C} 15)$ indicates that there was greater accumulation of $\mathrm{P}, \mathrm{C}, \mathrm{Zn}$ and $\mathrm{Mn}$ in the inoculated plants. This result shows a positive effect of inoculation on the accumulation of these elements in sunn hemp shoots, although the $\mathrm{N}$ accumulation between the subplots shows no significant difference ( $\mathrm{p} \leq 0.10$ ) for this contrast.

The non-significant effect of inoculants on the dry phytomass was also observed by Gualter et al. (2007) in cowpea [Vigna unguiculata (L.) Walp] inoculated with Bradyrhizobium elkanii in the Northeast region (Teresina, PI). The authors associated this result with the presence of native rhizobia populations that competed with the inoculum introduced. Araújo (1994) referred to the great survival skill of rhizobia in the soil when reporting the spontaneous and abundant nodulation in common bean cvs. Diamante Negro (black commercial 
Table 5. Mean contrasts and their significances for phytomass production (DM) and accumulations of macro and micronutrients in shoots relative to treatments with and without $\mathrm{N}$ fertilizer and/or with and without inoculation with $\mathrm{N} 2$-fixing bacteria of four green manure Fabaceae

\begin{tabular}{|c|c|c|c|c|c|c|c|c|c|c|c|}
\hline \multirow{2}{*}{ Contrasts $^{(1)}$} & MS & $\mathbf{N}$ & $\mathbf{P}$ & $\mathbf{K}$ & C & $\mathrm{Ca}$ & Mg & $\mathbf{F e}$ & $\mathbf{Z n}$ & Mn & $\mathbf{C u}$ \\
\hline & \multicolumn{11}{|c|}{$\left(k^{\prime} h^{-1}\right)$} \\
\hline $\mathrm{C} 4$ & 165.44 & -13.35 & 2.58 & 2.17 & 89.84 & 9.38 & 0.56 & 0.05 & 0.005 & -0.010 & -0.008 \\
\hline C5 & -187.09 & 13.58 & -1.39 & 11.26 & -82.01 & -11.75 & -2.62 & -0.08 & 0.020 & 0.010 & 0.002 \\
\hline C6 & -387.91 & -29.87 & -1.95 & -17.18 & -147.13 & 1.32 & -0.96 & -0.21 & -0.008 & -0.054 & -0.005 \\
\hline $\mathrm{C} 7$ & 340.10 & 15.24 & 1.93 & -2.19 & 136.33 & 2.06 & 0.25 & -0.08 & -0.006 & 0.010 & $-0.010^{\circ}$ \\
\hline $\mathrm{C} 8$ & -612.12 & 14.02 & -2.98 & -9.21 & -195.59 & -8.10 & -2.27 & -0.26 & -0.004 & 0.001 & -0.004 \\
\hline C9 & 113.67 & 1.83 & -0.78 & 20.51 & 76.42 & -1.02 & -0.34 & 0.44 & 0.049 & 0.017 & 0.007 \\
\hline $\mathrm{C} 10$ & 993.73 & $33.89^{\circ}$ & 3.21 & $20.56^{\circ}$ & 427.59 & -5.15 & -1.49 & $0.86 * *$ & 0.021 & 0.044 & 0.008 \\
\hline C11 & -812.67 & -27.24 & $-3.93^{\circ}$ & -9.81 & -335.11 & 10.48 & 0.55 & $-1.29 * *$ & -0.020 & $-0.085^{\circ}$ & -0.009 \\
\hline $\mathrm{C} 12$ & -729.27 & -30.15 & -0.98 & -13.91 & -301.17 & 14.69 & 0.76 & -0.50 & $-0.065^{*}$ & $-0.105^{*}$ & $-0.013^{\circ}$ \\
\hline $\mathrm{C} 13$ & -110.70 & -20.73 & 3.15 & 6.78 & -82.48 & -8.31 & -0.68 & -0.05 & -0.005 & 0.005 & -0.003 \\
\hline $\mathrm{C} 14$ & $-2771.34 *$ & -25.88 & $-6.54 * *$ & $-36.48^{*}$ & $-1253.84 * *$ & 8.37 & -1.23 & -0.26 & $-0.075^{*}$ & -0.060 & -0.005 \\
\hline $\mathrm{C} 15$ & 1734.73 & 13.90 & $6.78 * *$ & 16.78 & $768.70^{\circ}$ & -11.83 & -1.57 & 0.36 & $0.054^{\circ}$ & $0.083^{\circ}$ & -0.003 \\
\hline $\mathrm{CV}(\%)$ & 20.4 & 18.1 & 16.9 & 16.6 & 20.4 & 20.6 & 19.4 & 27.0 & 18.6 & 26.0 & 33.9 \\
\hline
\end{tabular}

${ }^{(1)}$ Contrasts: $\mathrm{C} 4=\mathrm{T} 1, \mathrm{~T} 2$ vs T3, $\mathrm{T} 4$ within $\mathrm{JB} ; \mathrm{C} 5=\mathrm{T} 2$ vs $\mathrm{T} 1$ within $\mathrm{JB} ; \mathrm{C} 6=\mathrm{T} 3$ vs $\mathrm{T} 4$ within $\mathrm{JB} ; \mathrm{C} 7=\mathrm{T} 1, \mathrm{~T} 2$ vs $\mathrm{T} 3$, $\mathrm{T} 4$ within $\mathrm{DP} ; \mathrm{C} 8=\mathrm{T} 2$ vs $\mathrm{T} 1$ within DP $\mathrm{C} 9=\mathrm{T} 3$ vs T4 within DP; $\mathrm{C} 10=\mathrm{T} 1, \mathrm{~T} 2$ vs T3, T4 within DM; $\mathrm{C} 11=\mathrm{T} 2$ vs T1 within DM; $\mathrm{C} 12=\mathrm{T} 3$ vs T4 within DM; 13 = T1, T2 vs T3, T4 within $\mathrm{SH} ; \mathrm{C} 14=\mathrm{T} 2$ vs T1 within $\mathrm{SH}$; and $\mathrm{C} 15=\mathrm{T} 3$ vs T4 within $\mathrm{SH} ; \mathrm{JB}=$ jack bean; $\mathrm{DP}=$ dwarf pigeon pea; $\mathrm{DM}=$ dwarf mucuna; $\mathrm{SH}=$ sunn hemp; vs = versus; $\mathrm{T} 1=\mathrm{CNSI}$ treatment (nitrogen, without inoculant); $\mathrm{T} 2=$ treatment $\mathrm{CNCI}$ (with nitrogen, with inoculant); $\mathrm{T} 3=\mathrm{SNCI}$ (without nitrogen, with inoculant); and T4 = SNSI (without nitrogen, without inoculant).

$\circ, *, * *$ significant at 10,5 and $1 \%$ probability by the $\mathrm{F}$ test.

Table 6. $\mathrm{N}$ accumulation in shoots of four green manure Fabaceae stratified between the treatments with $\mathrm{N}$ fertilization (with and without inoculant) and without $\mathrm{N}$ fertilization (with and without inoculant)

\begin{tabular}{|c|c|c|c|c|}
\hline \multirow[t]{2}{*}{ Treatment ${ }^{(1)}$} & Jack bean & Dwarf pigeon pea & Dwarf mucuna & Sunn hemp \\
\hline & \multicolumn{4}{|c|}{$\mathrm{N}$ accumulation $\left(\mathrm{kg} \mathrm{ha}^{-1}\right)$} \\
\hline $\mathrm{CNSI}^{1}$ & 199.61 & 189.01 & 193.67 & 204.23 \\
\hline $\mathrm{CNCI}^{2}$ & 213.18 & 203.03 & 166.43 & 178.35 \\
\hline $\mathrm{SNCI}^{3}$ & 204.81 & 181.70 & 131.08 & 218.97 \\
\hline $\mathrm{SNSI}^{4}$ & 234.68 & 179.87 & 161.23 & 205.07 \\
\hline Mean & 213.07 & 188.40 & 163.10 & 201.65 \\
\hline
\end{tabular}

(1)CNSI: With nitrogen and without inoculant; CNCI: With nitrogen and with inoculant; SNCI: Without nitrogen and with inoculant, and SNSI: Without nitrogen and without inoculation.

group) and Aporé (carioca group), without inoculation, in a field that had been pasture for 40 years before the introduction of beans, in the State of Goiás.

In general, the non-response to inoculation of the Fabaceae is probably because the native population of rhizobia is efficient to meet the $\mathrm{N}$ requirements of the crop, since satisfactory levels of $\mathrm{N}$ accumulated by the four tested species were achieved in the treatments without inoculation or nitrogen fertilization (Table 6).

\section{CONCLUSIONS}

Among the Fabaceae studied, the sunn hemp (Crotalaria juncea L.) was the most efficient in phytomass production and nutrient accumulation, while the dwarf mucuna [Mucuna deeringiana (Bort.) Merr.] was the least efficient, in the experimental and environmental conditions of this study.
There was no effect of the nitrogen fertilization or inoculation with $\mathrm{N}$-fixing bacteria on phytomass production or nutrient accumulation, except for the inoculation without nitrogen fertilization $(\mathrm{p}<0.05)$, which resulted in greater $\mathrm{P}$ accumulation in the sunn hemp and greater $\mathrm{Zn}$ and $\mathrm{Mn}$ accumulation in the dwarf mucuna. Thus, it is suggested that $\mathrm{N}$ fertilization and inoculation with $\mathrm{N}$-fixing bacteria are low efficiency practices for cultivation of the Fabaceae in the environmental conditions of this study.

\section{ACKNOWLEDGEMENTS}

The authors want to thank the Incaper for lending the study area and the logistical support, and FAPES and $\mathrm{CNPq}$ for the financial support. 


\section{REFERENCES}

Alvarez V VH \& Alvarez GAM (2006) Comparação de médias ou teste de hipóteses? Contrastes!Boletim Informativo da SBCS, 31:24-34

Amabile RF, Fancelli AL \& CarvalhoAM. (2000) Comportamento de espécies de adubos verdes em diferentes épocas de semeadura e espaçamentos na região dos Cerrados. Pesquisa Agropecuária Brasileira, $35: 47-54$.

Araújo RS (1994) Fixação biológica do nitrogênio em feijão. In: Araujo RS \&Hungria M (Eds.) Micro-organismos de importância agrícola. Brasília, Embrapa-CNPAF. p.91-120. (Documento n. ${ }^{\circ} 44$ ).

Bueno JRP, Sakai RH, Negrini AC, Ambrosano EJ \& Rossi F (2007) Caracterização química e produtividade de biomassa de quatro espécies de Mucuna. Revista Brasileira de Agroecologia, 2:901-904.

Calegari A, Mondardo A, Bulisani EA, Costa MBB, Miyasaka S \& Amado TJC (1993) Aspectos gerais da adubação verde. In: Costa MBB (Ed) Adubação verde no Sul do Brasil, $2^{\text {a }}$ ed. Rio de Janeiro, AS PTA. p.57-206.

Cantarella H (2007) Nitrogênio. In: Novais RF, Alvarez V VH, Barros NF Fontes RLF, Cantarutti RB \& Neves JCL (Eds.). Fertilidade do Solo. Viçosa, Sociedade Brasileira de Ciência do Solo. p.375-470.

Cavalcante VS, Santos VR, Santos Neto AL, Santos MAL, Santos CG \& Costa LC (2012) Biomassa e extração de nutrientes por plantas de cobertura. Revista Brasileira de Engenharia Agrícola e Ambiental, 16:521-528

Cherr CM, Scholberg JMS \& Mc SorleyR (2006) Green Manure Approaches to Crop Production: A Synthesis. Agronomy Journal, 98:302-319.

Cruz CD (2006) Programa Genes: Biometria. Viçosa, Editora UFV. 382p

EMBRAPA - Empresa Brasileira de Pesquisa Agropecuária (2009) Manual de análises químicas de solos, plantas e fertilizantes, $2^{\text {a }}$ ed. Brasília, Embrapa. 627p.

Embrapa Agrobiologia (2009) Base de dados de leguminosas. Disponível em: <http://www.cnpab.embrapa.br/leguminosas>. Acessado em: 30 de julho de 2009.

Epstein E \& Bloom AJ (2006) Nutrição mineral de plantas: Princípios e perspectivas. $2^{a}$ ed. Londrina, Planta. 403p.

Gualter RMR, Leite LFC, Alcantara RMCM, Costa DB \& Lima SS (2007) Avaliação dos efeitos da inoculação de feijão-caupi (Vigniaunguiculata [L.] Walp) com Bradyrhizobiumelkanii. In: $5^{\circ}$ Congresso Brasileiro de Agroecologia, Guarapari. Anais, Associação Brasileira de Agroecologia. CD-ROM.

Jarrel WM \& Beverly RB (1981) The dilution effect in plant nutrition studies. Advances in Agronomy, 34;197-224.

Leal MAA, Guerra JGM, Peixoto RTG \& Almeida DL (2012) Desempenho de crotalária cultivada em diferentes épocas de semeadura e de corte. Revista Ceres, 59:386-391.

Lima AA, Fernandes Junior PI, Passos SR, Paulo FS, Nosoline SM, Faria SM, Guerra JGM, Rumjanek NG\&Xavier GR (2012) Diversidade e capacidade simbiótica de rizóbios isolados de nódulos de MucunaCinza e Mucuna-Anã. Revista Brasileirade Ciência do Solo, 36:337348.

Long SR (2001) Genes andsignals in theRhizobium-legume symbiosis. Plant Physiology, 125:69-72.

Marschner H (1997) Mineral nutrition of higher plants. 2 ${ }^{\mathrm{a}}$ ed. London, Academic Press. 889p.

Matos ES, Mendonça ES, Cardoso IM, Lima PC \&Freese D (2011) Decomposition and nutrient release of leguminous plants in coffee agroforestry systems. RevistaBrasileira de Ciência do Solo, 35:141149.
Matos ES, Mendonça ES, Lima PC, Coelho MS, Mateus RF \& Cardoso IM (2008) Green manure in coffee systems in the region of Zona da Mata, Minas Gerais: Characteristics and kinetics of carbon and nitrogen mineralization. Revista Brasileira de Ciência do Solo, 32:20272035.

Miyasaka S (1984) Histórico do estudo de adubação verde, leguminosas viáveis e suas características. In: Adubação Verde no Brasil. Campinas, Fundação Cargill. p.64-123.

Monquero PA, Côrrea MC, Barbosa LN, Gutierrez A, Orzari I \& Hirata ACS (2013) Seleção de espécies de adubos verdes visando à fitorremediação de diclosulam. Planta Daninha, 31:127-135, 2013.

Moreira FMS \& Siqueira JO (2006) Microbiologia e bioquímica do solo. $2^{a}$ ed. Lavras, Editora UFLA. 729p.

Nwaichi EO, Wegwu MO \&Onyeike EM (2009) Phytoextracting cadmium and copper using Mucunapruriens. African Journal of Plant Science, $3: 277-282$.

Omosun G, Edeoga HO, Markson AA\&Madunagu BE (2010) Uptake of lead, nickel and copper by three mucuna species.International Journal of Current Research, 4:98-103.

Pereira GAM, Silva DV, Braga RR, Carvalho FP, Pereira EA \& Santos JB (2012) Fitomassa de adubos verdes e cobertura do solo na região do Alto Vale do Jequitinhonha, Minas Gerais. Revista Agroambiente On-line, 6:110-116.

Pereira JP, Guerra JGM, Moreira VF, Teixeira MG, Urquiaga S, Polidoro JC \& Espíndola JAA (2005) Desempenho agronômico de Crotalariajuncea em diferentes arranjos populacionais e épocas do ano. Seropédica, Embrapa Agrobiologia, Embrapa-CNPAB. 20p. (Comunicado técnico $\mathrm{n}^{\circ} 82$ ).

Prezotti LC, Gomes JA, Dadalto GG \& Oliveira JA (2007) Manual de recomendação de calagem e adubação para o Estado do Espírito Santo. $5^{\text {a }}$ aproximação. Vitória, SEEA/ INCAPER/CEDAGRO. 305p.

SAEG (2005) Sistema para análises estatísticas, Versão 9.1 (Demonstração): Viçosa, Fundação Arthur Bernardes/UFV. CD-ROM.

Santos WS \& Campelo Júnior JH. (2003) Influência dos elementos meteorológicos na produção de adubos verdes, em diferentes épocas de semeadura. Revista Brasileira de Engenharia Agrícola e Ambiental, 7:91-98.

Silva EE (2006) Manejo orgânico da cultura da couve em rotação com o milho, consorciados com leguminosas para adubação verde intercalar em plantio direto. Dissertação de Mestrado. Seropédica, Universidade Federal Rural do Rio de Janeiro. 69p.

Taiz L \& Zeiger E (2009) Fisiologia Vegetal. $4^{\mathrm{a}}$ ed. Porto Alegre, Armed. $848 \mathrm{p}$

Teodoro RB, Oliveira FL, Silva DMN, Fávero C \& Quaresma MAL (2011) Aspectos agronômicos de leguminosas para adubação verde no Cerrado do Alto do Jequitinhonha. Revista Brasileira de Ciência do Solo, 35:635-643.

Vendruscolo D (2013) Seleção de plantas para fitorremediação de solo contaminado com cobre. Dissertação de Mestrado. Santa Maria, Universidade Federal de Santa Maria. 57p.

Vieira RF (2007) Diversidade e Taxonomia de Rizóbio. In: Silveira APD \& Freitas SS (Eds.) Microbiota do Solo e Qualidade Ambiental. Campinas, Instituto Agronômico. p.165-192. 